\section{West Nile virus up in 2005}

A surge in the number of deaths from West Nile virus in Canada last year compared with 2004 was likely due to hotter weather.

As of Oct. 29, I2 deaths and 172 confirmed human cases of the virus had been reported to the Public Health Agency of Canada (Table I). In 2004, only 2 people died; in 2003, there were I2 deaths and in 2002, 20.

In the US, the number of deaths dropped to 73 from 79 in 2004, 264 in 2003 and 582 in 2002. But a medical epidemiologist with the US Centers for Disease Control would not call the diminishing death rate a trend. It's impossible to accurately predict what will happen in 2006, says Dr. Grant Campbell. "There are so many variables involved."

These variables include climate, weather, bird migration, immunity and reproduction.

Mike Drebot, head of Health Canada's Viral Zoonoses Section of the Canadian Centre for Human and Animal Health, says this year's surge may have occurred because most regions had a hotter summer than in 2004.

Winnipeg, for example, had an "unprecedented" hot and wet summer, leading to record-breaking numbers of mosquitoes, according to the city's entomologist, Taz Stuart. This led the city to use larvicides and to "fog" sections of the city with insecticide on a nightly basis for nearly a month. Despite these efforts, there were 46 confirmed cases and one reported death from WNV in Manitoba in 2005. In 2004, Manitoba had no deaths and no confirmed cases, and in 2003 the province reported 2 deaths and 39 confirmed cases.

Table 1: Confirmed human cases and deaths from West Nile virus infection in Canada, 2002-2005

\begin{tabular}{crc}
\hline Year & $\begin{array}{c}\text { Confirmed } \\
\text { cases }\end{array}$ & Deaths \\
\hline 2002 & 340 & 20 \\
2003 & 1319 & 12 \\
2004 & 16 & 2 \\
2005 & 172 & 12 \\
\hline
\end{tabular}

Source: Health Canada, Public Health Agency of Canada.

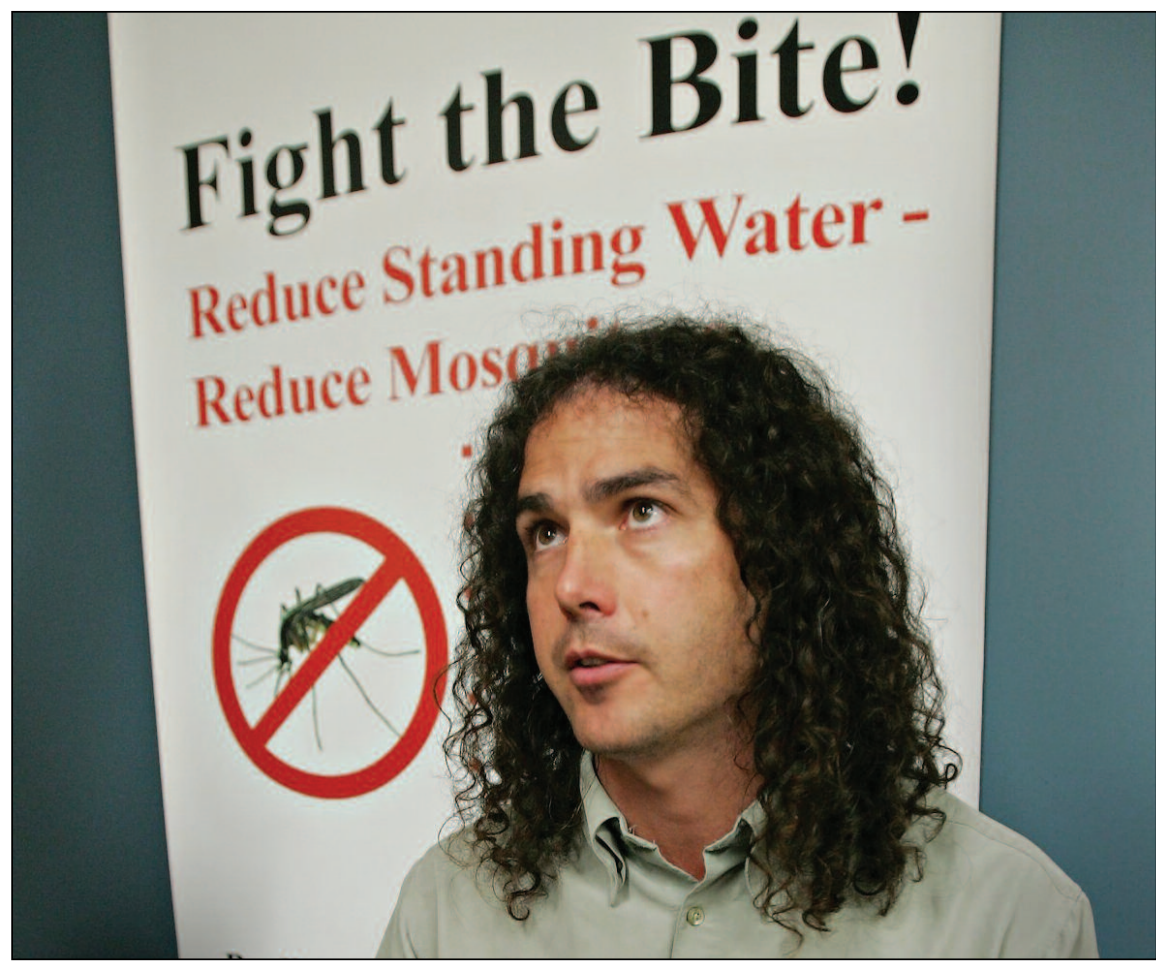

Winnipeg entomologist Taz Stuart in 2005 explaining plans to fog neighbourhoods with insecticide in view of high counts of mosquitoes. There were 46 confirmed cases and 1 death from WNV in Manitoba last year.

Saskatchewan reported 8 confirmed cases and 2 deaths in 2005. Ontario had the largest number of confirmed cases this year (9I) as well as 8 deaths. Southern Ontario's hot summer was a contributing factor, says Drebot.

Overall, the number of cases and deaths have been declining in Canada and the US since 2002. Experts attribute the decline to preventive measures such as removing standing water, spraying and wearing mosquito repellant, as well as to increased immunity in host birds.

"There may not be as many reservoir birds for the virus, which could affect case rates," says Drebot, adding that research is required to confirm this.

In 2005, 447 birds tested positive for the virus in Canada, compared to $4 \mathrm{I} 6$ in 2004 and 1632 in 2003.

Drebot is encouraged by the fact that some strains of the virus found in Mexico and Texas seem to have become less virulent. In addition, between $2 \%$ and $5 \%$ of North Americans have been exposed to the virus and may be immune. "We may never see the large epidemics in Canada that we saw in 2002 and 2003," he says.

Although the virus is lingering in central Canada, it has moved west in the US, likely following the migratory routes of birds, says Campbell. - Kristen Everson, Ottawa

DOI:I0.1503/cmaj.05I434

\section{Museum in India tackles}

\section{HIVIAIDS}

$\Lambda$ municipality in western India is using a sex museum to educate people about HIV/AIDS and safe sex.

The Antarang museum in Mumbai uses excerpts from India's ancient books, including the Kama Sutra and Kumarsambhabam, to describe the sexual relationship between men and women. Paintings and sculpture depict the basics of love, reproduction and HIV/AIDS. Exhibits also illustrate condom use and safe sex, and discuss the dangers of unprotected sex, the preva- 
lence of HIV/AIDS in India and its social stigma.

An estimated 5.13 million people in India are infected with HIV, the highest number of infections in the world after South Africa (CMAJ 2004;I7I:I337-8). The southern states, where Mumbai is located, account for $30 \%$ of India's population but $75 \%$ of HIV-I cases.

The museum is a collaborative venture by the Brihanmumbai Municipal Corporation and the Mumbai District AIDS Control Society. When it opened in 2002, it attracted some 25000 visitors annually. Now, the numbers have tapered off, largely due to a lack of publicity and the social stigma surrounding HIV/AID in India. Precise attendance figures are not available.

Nonetheless, the museum is effective, maintains Swapan Jana, secretary of society for Social Pharmacology India, a non-governmental organization working on HIV/AIDS education and prevention. "Sex education provided by the museum has really helped save lives of people," he says.

If Antarang's operators maintain the museum and pitch it toward young people, it may be more successful than traditional approaches to combating HIV/ AIDS, he adds.

"In India, approaches carried out with posters, leaflets, free condoms, auto-disposable syringes and television publicity seem to have very limited impact in combating HIV/AIDS, because most of them couldn't attract the common people," says Jana. "Antarang is an attractive approach [and] it should work properly, reaching the target population." — Manjulika Das, Kolkata, India

DOI:I0.I503/cmaj.051297

\section{News@ a glance}

Rapid HIV test: Health Canada has approved a rapid HIV test kit, developed by a Canadian company, that will allow doctors, emergency health care workers or hospital personnel to test patients on the spot. The INSTI HIV kit uses a finger prick to detect the presence of HIV antibodies in blood, plasma or serum, returning a result within 6o seconds. Clinical trials demonstrated a $99.6 \%$ accuracy test, says bioLytical Laboratories of Richmond, BC, which developed the test. If someone receives a positive finding from the test, bioLytical considers that a "presumptive positive" requiring a follow-up lab test. Currently, patients who send HIV tests to laboratories can wait up to Io days for results. Although there are several similar kits available in the US, this is the first approved for use in Canada. The company is negotiating with the provinces to make it available to physicians and others, and to make sure that data on those who test negative, as well as positive, are still recorded, as is now the case with laboratory testing. The ease and accuracy of the test should encourage more people to get tested, says Richard Galli, director of research and development at bioLytical. "We're hoping that this will in fact bring forward a large segment of the population that hasn't come forward yet."

Hep C sidestep: It took a year, but the federal government has finally laid out the steps necessary to compensate people who contracted hepatitis C from tainted blood before 1986 and after 1990. In November 2004, Health Minister Ujjal Dosanjh said he hoped to resolve this issue by June 2005 (CMAJ 2005;172:25). Instead, lawyers for government and the victims negotiated for a year. The next steps now include collecting information about the number of people to be compensated (estimated at 6000 to 10 000), their health status and prognosis. All this information should already be on hand, says the Canadian Hemophilia Society, which is fed up with delays. "The lack of information speaks to an overall failure of governments," states

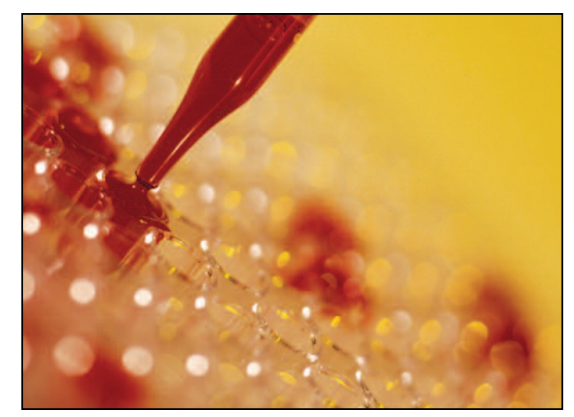

spokesperson John Plater. It will be several months before people are compensated, says Dosanjh.

Media doctor: A dozen academics are tackling inaccuracy in medical news reporting at www.mediadoctor.ca. The site rates treatment stories on a 5star scale. Two reviewers, drawn from a bank of Io from the UBC Faculty of Pharmaceutical Sciences and Media Studies Unit, run stories through an II-point checklist. For example, the report, "Do age-old remedies stop the sneezing?" (Calgary Herald, Nov. I7, 2005) garnered 2 stars, because there was no reference to the quality of evidence, the benefit or harm of the treatments or their cost. The site, which is modelled on Media Doctor Australia, was launched by Alan Cassels at the University of Victoria School of Health Information Science. Cassels and his counterpart in Australia plan to eventually include news on other topics such as diagnostic tests and surgery, and to run international comparisons of media coverage. The Canadian site got start-up funding of $\$ 65000$ from Industry Canada.

Drugged driving: Teenagers are more likely to drive after using marijuana than after drinking alcohol, finds a new study (Accid Anal Prev 2005;37:102534). Researchers surveyed teenagers in Atlantic Canada and found $15.1 \%$ of students, age 16 to 18 , had driven under the influence of cannabis, whereas II. $7 \%$ had driven under the influence of alcohol. The study showed $62.3 \%$ of students had used alcohol but only $33.6 \%$ had used cannabis. After alcohol, "cannabis is the drug most often found in drivers who are fatally injured," the study reported. - Kristen Everson, Ottawa

More physicians: Ontario is investing $\$ 33$ million over 3 years to train an additional I4I family physicians annually. Ontario now graduates I96 FPs annually. The money will be spent on construction (\$ro million) at 4 universities, and on operating costs ( $\$ 23$ million). — Compiled by Barbara Sibbald, $C M A J$

DOI:I0.1503/cmaj.051518 